\title{
MÚSICA ESPECTRAL
}

Carmen $\mathrm{Moral}^{1}$

Los computadores modernos han hecho posible analizar el sonido y comprender su estructura. La música espectral está basada en el descubrimiento de la naturaleza del sonido y la composición de su espectro.

En los años setenta, un grupo de jóvenes compositores franceses se interesan por los nuevos hallazgos. Ellos son, entre otros, Michael Levinas, Hugues Dufourt, Tristan Murail y Gérard Grisey.

Este último nos dice que el espectralismo no es un sistema tal como el de los que preconizan la música dodecafónica o la música tonal, sino una actitud que considera a los sonidos no como objetos muertos, fácil y arbitrariamente permutables en todas las direcciones. Los considera como seres vivientes con un nacimiento, vida y muerte. Puntualizan que, ya antes, Edgar Varese -a quien consideran un precursor del movimiento- pensaba en esta dirección.

Por su parte, Tristan Murail nos cuenta cómo llegó a la música espectral. Su profesor Olivier Messiaen consideraba que la música serial era muy avanzada y que todo compositor joven debería usarla como técnica de composición, cosa que hizo, pero pronto se dio cuenta de que esa técnica no le convenía. Él tenía imágenes de sonidos e ideas musicales que no podía expresar con la música serial o dodecafónica. Tenía que encontrar entonces otro camino para su desarrollo como compositor.

Messiaen tenía por costumbre invitar a su clase a compositores para que presentasen su propia música. Fue así como Murail pudo entrar en contacto con Iannis Xenakis y Georgy Ligeti, los cuales tenían en común el uso de masas de sonidos y procesos, es decir, cuando una situación musical se transforma en una nueva, muy diferentes a la antigua noción de desarrollo musical, estos compositores protoespectrales le mostraron que había otros caminos para la composición.

En 1980, Murail comienza una larga asociación con el Institut de Recherche et Coordination Acoustique/Musique IRCAM, en donde los computadores del instituto le permiten explorar la vida interna del sonido. Resume su manera de componer así: Hago música trabajando la materia del sonido como un escultor, revelando la forma oculta dentro del bloque de piedra, en lugar de construir con ladrillos, como se hace tradicionalmente.

Fue Hugues Dufourt quien dio al naciente estilo su nombre cuando en 1979 escribe un artículo intitulado Música Espectral. Allí observa que esta música está basada en el desarrollo del espectro o grupo de espectros que están en constante evolución y tienen un impacto en el movimiento armónico.

Todo el material de la música espectral se deriva de las propiedades acústicas del sonido y de los diferentes espectros. De allí viene su nombre.

La aparición de la música espectral está íntimamente unida al desarrollo y sofisticación de los computadores que hacen posible analizar el sonido y su comportamiento. La música espectral está altamente influenciada por las técnicas electrónicas.

1 B.M. (Bachelor of Music), M.M. (master of music) en Manhattan School of Music en Nueva York, M.M. en la Universidad de Columbia (Nueva York) y Master y un DEA de la Universidad Sorbona (París), es directora orquestal y compositora peruana. 
Giacinto Scelsi, conocido por su obsesión por examinar un único sonido y descomponerlo, y Edgard Varese, para quien la música era el arte de escuchar y dejar escuchar la corporificación del sonido, figuran junto a compositores que se remontan hasta Richard Wagner con su Preludio al Oro del Rin, como los precursores de esta actitud ante el sonido, llamada música espectral.

Fecha de recepción: 14-05-18.

Fecha de aceptación:14-06-18 